\title{
PHYTOCHEMICAL AND BIOLOGICAL STUDY OF (Senecio glaucus subsp. coronopifolius ) (MAIRE) C. ALEXANDER GROWING IN EGYPT
}

\author{
BY
}

\author{
Shaza A. Mohamed
}

FROM

Pharmacognosy Department, Faculty of Pharmacy (Girls), AL-Azhar University, Cairo, Egypt.

\begin{abstract}
Senecio glaucus subsp. coronopifolius (Maire) C. Alexander is wild annual herb distributed in the Egyptian deserts. Total phenolic and flavonoid content of plant root were determined using both HPLC and colorimetric analysis. Syringic acid and hesperidin (1378.802 and $6638.247 \mathrm{mg} / 100 \mathrm{gm}$. dried plant root powder, respectively) were of the highest concentration compounds resulted from HPLC analysis of total phenolic and flavonoid content. The colorimetric estimation of total phenolic and flavonoid content resulted in concentration of $(98.23 \pm 0.28 \mathrm{mg} / \mathrm{gm}$. expressed as Gallic acid equivalent (GAE) and $35.9 \pm 0.17 \mathrm{mg} / \mathrm{gm}$. expressed as quercetin equivalent (QE), respectively). GC-MS analysis of un-saponifiable matters and fatty acid methyl esters of the plant leaves indicated that octacosane (11.85\%) and linolenic acid methyl ester $(31.07 \%)$ (poly- unsaturated fatty acid) were the major identified compounds, respectively. The DNA of the plant was analyzed using twelve random decamer primers. A total of 52 random amplified polymorphic DNA (RAPD) markers were identified. Root extracts (ethyl acetate, acetone and methyl alcohol) were subjected to determine the antimicrobial behavior and also their cytotoxic activity, by using (3- $(4,5-$ dimethylthiazolyl-2)-2, 5-diphenyltetrazolium bromide) (MTT) assay against colon carcinoma cell lines (HCT-116). Among the fore mentioned extracts, root ethyl acetate extract gave appreciable antibacterial and antifungal behavior and also had promising cytotoxic activity with $I C_{50}=7.39 \pm 1.2 \mu \mathrm{g} / \mathrm{ml}$. Root methyl alcohol extract showed antioxidant activity with $I C_{50}=79.57 \pm 0.74 \mu \mathrm{g} / \mathrm{ml}$, using 2, 2-diphenyl-1picrylhydrazyl (DPPH) assay.
\end{abstract}

\section{KEY WORDS}

Senecio glaucus subsp. coronopifolius (Maire) C. Alexander, Asteraceae, phenolic acids, flavonoids, cytotoxic, antimicrobial and antioxidant activities.

\section{INTRODUCTION}

Senecio is the largest and most complex genus of family Asteraceae with about 1500 species and with worldwide distribution (Nordenstam, 1977). The species are distributed especially in South Africa, Mediterranean regions and in temperate areas of Asia and America (Schishkin and Bobrov, 1995). A few herbaceous species of the genus are grown as ornamental plants (Joffe, 2001). Literature reported that Senecio 
species showed a large variety of sesquiterpenoids (Bohlmann and Ziesche, 1981), diterpenoids (Rucker et al., 1999), triterpenoids (Cheng et al., 1993), volatile oils (Perez et al., 1999) and alkaloids (Bohlmann et al., 1986). In traditional medicine, the use of Senecio species for treatment of asthma, coughs, bronchitis, eczema and wound healing have been reported (Joshi et al., 2013). Senecio glaucus L. is an annual herb with two subspecies (subsp.) which grow in Egypt .The first subsp. is Senecio glaucus L. subsp. glaucus and the second is Senecio glaucus subsp. coronopifloius (Maire) C. Alexander [synonyms: Senecio coronopifloius Desf., Senecio laxiflorus Viv. and Senecio desfontaiei Druce]. Subsp. coronopifloius grows in coastal sandy, saline soils, dessert wadis and edges of cultivation and it is much more widespread throughout Egypt than subsp. glaucus (Boulos, 2002). The volatile constituents of S. glaucus subsp. coronopifloius had been estimated; the results revealed that myrcene $(24 \%)$ and dehydrofukinone $(21 \%)$ were the major components (De Pooter et al., 1986; ElShazly, 1999). Many studies determined the alkaloid profile and the phytochemical investigation of the aerial parts of $S$. desfontainei Druce (Gharbo and Habib, 1969; Habib, 1981; El-Shazly, 2002; Mansour and Saleh, 1981; Hussain et al., 2013).

As no previous studies were performed to investigate the phytochemistry of the roots and DNA fingerprinting of Senecio glaucus subsp. coronopifolius this work was undertaken to investigate Senecio glaucus subsp. coronopifolius roots from some phytochemical and biological aspects, analyze DNA fingerprinting and the lipid profile of its leaves.

\section{MATERIAL AND METHODS:}

\section{1-Plant material:}

The entire plant of Senecio glaucus subsp. coronopifolius in the flowering stage was collected in March, 2013 from Cairo- Ismailia Road. The plant was identified by Dr. Abdel-Halim Abdel-Mogaly, Herbarium of Horticultural Research Institute, Agricultural Research Centre, Dokki, Giza, Egypt, according to (Boulos ,2002). Voucher specimen was deposited in faculty of pharmacy (girls), AL-Azhar University (SG 001). The plant was divided into root portion (for phytochemical and biological investigation) and leaf portion (for DNA fingerprinting and lipid content analysis) and each portion was separately air dried.

\section{2-Preparation of the plant extracts:}

The dried powder of the plant root under the study (200 gm.) was exhaustively extracted with $70 \%$ methanol. The combined methanolic extracts were filtered and concentrated under vacuum. The residue obtained was $15 \mathrm{gm}$. Part of the obtained concentrated mehtanolic extract residue $(10 \mathrm{gm}$.) was exhaustively extracted with ethyl acetate and acetone. The combined ethyl acetate and acetone extracts were filtered and concentrated under vacuum. The yields of concentrated ethyl acetate and acetone extract residues were $3.5 \mathrm{gm}$. and $2 \mathrm{gm}$., respectively. 
Fresh leaves of the plant (150 gm.) were dried, ground and defatted with petroleum ether. The extracts were combined, filtered and concentrated under vacuum. The residue obtained ( $3 \mathrm{gm}$.) was kept for investigation of lipid content.

\section{3-HPLC analysis of total phenolic and flavonoid content:}

\section{Preparation of the sample:}

Dry powder of Senecio glaucus subsp. coronopifolius roots (one gm.) was weighed into a $100 \mathrm{ml}$ conical flask then dispersed in $40 \mathrm{ml}$ of $62.5 \%$ aqueous methanol. The mixture was then ultra-sonicated for $5 \mathrm{~min}$., $10 \mathrm{ml}$ of $6 \mathrm{M} \mathrm{HCL}$ was added. Hydrolysis was carried out in a water bath at $90{ }^{\circ} \mathrm{C}$ for 2 hrs. After hydrolysis, the sample was cooled, filtered, made up to $100 \mathrm{ml}$ with methanol, and ultra-sonicated for $5 \mathrm{~min}$. Before quantification by HPLC, the sample was filtered through a $0.4 \mu \mathrm{m}$ membrane filter into the sampler vial for injection by using HPLC AGILENT 1100 series adopting the following conditions; ODS column with dimension of (4 x150 mm, $3 \mu \mathrm{m}), 35^{\circ} \mathrm{C}$ oven temperature, $0.7 \mathrm{ml} / \mathrm{min}$. flow rate, injection volume was $5 \mu \mathrm{l}$ of the standards and $40 \mu \mathrm{l}$ of sample extract and it was equipped with UV detector of $330 \mathrm{~nm}$ for flavonoids and $280 \mathrm{~nm}$ for phenolic compounds. The relative concentration of each of the detected phenolic compounds and flavonoids was determined by the regression equation (Mattila et al., 2000). The analysis was performed at Agricultural Research Center, Giza.

\section{4- Colorimetric estimation of total phenolic content:}

The total phenolic content of Senecio glaucus subsp. coronopifolius root methanolic extract was quantified using Folin-Ciocalteau reagent and gallic acid as standard, at $\lambda_{\max }=765 \mathrm{~nm}$ (Sellappan et al., 2002). Calculations were based on gallic acid calibration curve where the total phenolics were expressed as milligram of gallic acid equivalent (GAE) per gram dry extract and all measurements were carried out in triplicate. Colorimetric estimation of total phenolic content was explored at the Regional Center for Mycology and Biotechnology (RCMB), Al-Azhar University.

\section{5- Colorimetric estimation of total flavonoid content:}

Total flavonoid content of plant root methanolic extract was determined using aluminium chloride colorimetric assay (Kosalec et al., 2004), where the measurement was performed at $\lambda_{\max }=415 \mathrm{~nm}$. Calculations were based on quercetin calibration curve and the total content was expressed as milligram of quercetin equivalent (QE) per gram dry extract. All measurements were carried out in triplicate and it was estimated at the Regional Center for Mycology and Biotechnology (RCMB), Al-Azhar University.

\section{6- Investigation of lipid content:}

\section{A - Saponification and separation of un-saponifiable and saponifiable matters:}

Dried residue (one gm.) of leaf petroleum ether extract was saponified for 5 hours with ethanolic $\mathrm{KOH}(20 \%)$ at room temperature. The saponified extract was concentrated to $1 / 3$ its volume. The cooled reaction mixture was diluted with an equal 
volume of distilled water and exhaustively extracted with ether (negative test for sterols). The combined ethereal extract was washed several times with water till free of alkalinity and dehydrated over anhydrous sodium sulphate. After evaporation of ether to dryness, the residue $(0.15 \mathrm{gm}$.) was kept for GC-MS analysis of un-saponifiable matter. The alkaline aqueous solution remaining after extraction of the un-saponafiable matter was acidified with hydrochloric acid to liberate the fatty acids which were extracted several times with ether. The combined ethereal extract was washed several times with distilled water till free of acidity, and then filtered over anhydrous sodium sulphate, and the filtrate was evaporated to dryness (0.25 gm.) (Vogel, 1989).

\section{B- Preparation of fatty acid methyl esters (FAME):}

The prepared fatty acids, as well as the standard fatty acids were dissolved in a small amount of anhydrous methanol and methylated by drop-wise addition of diazomethane ethereal solution until gas evolution ceased and the mixture acquired a pale yellow color indicating the addition of excess diazomethane. The reaction mixture was left for $10 \mathrm{~min}$. then ether was evaporated under nitrogen stream at room temperature. Two drops of redistilled chloroform solution were added to dissolve the FAME and the solution was kept in a desiccator for GC-MS analysis of fatty acid content (saponifiable matters) (Vogel, 1989).

\section{C- GC/MS analysis of un-saponifiable matters:}

The analysis was performed at the National Research Center, Dokki, Giza. Samples $(1 \mu 1$, each) was injected into GC/MS equipped with Mass Selective detector (MSD) for analysis of un-saponifiable matter [Thermo Trace Ultra and ISQ single quadrupole MS for GLC and mass analysis respectively] with capillary column TR$5 \mathrm{MS}\left(30 \mathrm{~m} \times 0.25 \mathrm{~mm}\right.$ ID $\times 0.25 \mu \mathrm{m}$ film) $50{ }^{\circ} \mathrm{C}$ oven temperature and temperature increased to $300{ }^{\circ} \mathrm{C}$ by the rate of $5{ }^{\circ} \mathrm{C} / \mathrm{min}$, carrier gas was helium with flow rate of $1.5 \mathrm{ml} / \mathrm{min}$ and with $200{ }^{\circ} \mathrm{C}$ injector temperature. The ionization energy was $70 \mathrm{eV}$ and the qualitative identification of the different constituents was performed by comparison of their relative retention times and mass spectra with those of authentic reference compounds. Also, probability merge search software, Wiley 9, Main lib. and the NIST MS spectra search program were used.

\section{D- GC/MS analysis of fatty acid methyl esters:}

The analysis was performed in Faculty of Agriculture (chemistry lab.), Cairo University, Giza, using the following condition: [HP 6890 and 5973 Series (AGILENT) for GLC and mass analysis respectively] with capillary column TRFAMS (30 m x $0.25 \mathrm{~mm}$ ID x $0.25 \mu \mathrm{m}$ film), $80{ }^{\circ} \mathrm{C}$ oven temperature and temperature increased to $230{ }^{\circ} \mathrm{C}$ by the rate of $3{ }^{\circ} \mathrm{C} / \mathrm{min}$, carrier gas was helium with flow rate of $1.5 \mathrm{ml} / \mathrm{min}$ and with $200{ }^{\circ} \mathrm{C}$ injector temperature. The ionization energy was $70 \mathrm{eV}$ and the qualitative identification of the different constituents was performed by comparison of their relative retention times and mass spectra with those of authentic reference compounds. Also, probability merge search software and the NIST MS spectra search program were used. 


\section{7- DNA Fingerprinting using Random Amplified Polymorphic-DNA-PCR:}

\section{A- DNA extraction:}

Samples of fresh leaves of Senecio glaucus subsp. coronopifolius stored at $-70^{\circ}$ $\mathrm{C}$, freeze dried and ground under liquid nitrogen to fine powder.DNA was extracted from $10 \mathrm{gm}$. of leaf tissue in micro-centrifuge tubes using DNA extraction method (Williams et al., 1990).

\section{B- Oligonucleotide primers:}

A total of 12 random decamer oligonucleotide primers from A,D,F, G,H,M,P and Q kits ( Operon Technologies Inc.) having the following sequences : A-03(AGTCAGCCAC),A-15(TTCCGAACCC),D-11(AGCGCCATTG), D-12(CACCGTATCC), D-19(CTGGGGACTT),F-09(CCAAGCTTCC), G20(TCTCCCTCAG), H-13(GACGCCACAC), M-19(CCTTCAGGCA), P-11 (AACGCGTCGG), Q-5(CCGCGTCTTG) and Q-11 (TCTCCGCAAC).

\section{C- Polymerase Chain Reaction (PCR):}

The amplification reaction was carried out in $25 \mu 1$ reaction volume containing $2.5 \mu 110$ X PCR buffer, $2 \mu \mathrm{MgCl}_{2}, 2.5 \mu \mathrm{l}$ deoxynucleoside triphosphate (dNTPs), $3 \mu 1$ primer, $0.3 \mu \mathrm{l}$ Taq DNA polymerase and $3 \mu \mathrm{l}$ templates DNA following a thermal cyclic program. The PCR temperature profile was applied through a thermocycler [Gene Amp ${ }^{\circledR}$ PCR System 9700 (Perkin Elmer, England)].The thermocycler was programmed for one cycle of five minutes for initial strand separation at $94{ }^{\circ} \mathrm{C}$ and for 40 cycles each one minute at $94{ }^{\circ} \mathrm{C}$ for denaturation, one minute for primer annealing at $36{ }^{\circ} \mathrm{C}$, ninety seconds for primer elongation at $72{ }^{\circ} \mathrm{C}$, followed by one cycle of final primer extension at $72{ }^{\circ} \mathrm{C}$ for seven minutes. The amplified products were resolved by electrophoresis in a $1.5 \%$ agarose gel containing ethidium bromide $(0.5 \mu \mathrm{g} / \mathrm{ml})$ in $1 \mathrm{X}$ Tris /Borte /EDTA (TBE) buffer at 95 volts. PCR products were visualized in UV light and photographed using Polaroid camera type 57 (ASA 3000). A molecular size marker was used as standard marker (Thermo scientific, Gene Ruler, Ladder, Korea). All DNA fingerprinting procedures were performed in Agricultural Research Center, Giza.

\section{D- Analysis of RAPD data:}

RAPD bands were treated as present or absent, without considering their percentage. Clear and distinct amplification products were scored as $(+)$ for presence and (-) for absence of bands.

\section{8- Antimicrobial activity:}

Antimicrobial activity was explored at the Regional Center for Mycology and Biotechnology (RCMB), Al-Azhar University. Different root extracts (ethyl acetate, acetone and methyl alcohol) were evaluated against gram positive bacteria (Staphylococcus aureus and Bacillus subtilis), gram negative bacteria (Klebsiella pneumonia and Salmonella typhimurium), Fungi (Aspergillus fumigates and Syncephalastrum racemosum) and Candida albicans using the following methods: 


\section{A- Sensitivity tests by Kirby-Bauer method (disc diffusion method):}

Antimicrobial activity of the tested samples was determined using a modified Kirby-Bauer disc diffusion method (Bauer et al., 1966). $100 \mu 1$ of the test bacteria/fungi were grown in $10 \mathrm{ml}$ of fresh media until they reached a count of approximately 108 cells $/ \mathrm{ml}$ for bacteria or 105 cells $/ \mathrm{ml}$ for fungi (Pfaller et al., 1988). Microbial suspension $(100 \mu \mathrm{l})$ was spread onto agar plates corresponding to the broth in which they were maintained. Standard discs of ampicillin, gentamycin (antibacterial agents) and amphotericin B (antifungal agent) served as positive controls for antimicrobial activity but filter discs impregnated with $10 \mu \mathrm{l}$ of solvent (DMSO) were used as a negative control. Blank paper discs (Schleicher \& Schuell, Spain) with a diameter of 8.0 $\mathrm{mm}$ were impregnated with $10 \mu \mathrm{l}$ of tested extracts.

\section{B- Minimum Inhibitory Concentration (MIC) determination using agar dilution method:}

Standardized bacterial suspensions were prepared to a final cell density of $6 \mathrm{x}$ $10^{5}$ Colony Forming Units $/ \mathrm{ml}$ (CFU / ml) .Serial dilutions from root ethyl acetate extract $(0-320 \mu \mathrm{g} / \mathrm{ml})$ were prepared and mixed with $5 \mathrm{ml}$ of the standardized bacteria suspension then added to the plates and incubated for $24 \mathrm{~h}$ at $37{ }^{\circ} \mathrm{C}$. CFU were counted for each dilution (NCCLS, 1997).

\section{9- Cytotoxic activity:}

Cytotoxic activity was explored at the Regional Center for Mycology and Biotechnology (RCMB) at Al-Azhar University. Senecio glaucus subsp. coronopifolius root (ethyl acetate, acetone and methyl alcohol) extracts were tested against colorectal carcinoma cell line (HCT-116), utilizing MTT (3-(4, 5-dimethylthiazolyl-2) - 2, 5diphenyltetrazolium bromide) test in triplicate (Fotakis and Timbrell, 2006). Untreated cells represented the negative control while doxorubicin was the positive control. The absorbance was measured at $570 \mathrm{~nm}$ using a microplate ELISA reader (Sun Rise TECAN, Inc, USA). The absorbance of untreated cells was considered as $100 \%$. The results were determined by three independent experiments (Wilson, 2000). The percentage cell viability was calculated with the Microsoft Excel®. Percentage cell viability was calculated as follows: $\%$ Cell viability $=($ Mean Abs control - Mean Abs test metabolite X 100) / Mean Abs control, where: Abs: absorbance at $570 \mathrm{~nm}$. The graphic plots were used for estimation of the $50 \%$ inhibitory concentration $\left(I C_{50}\right)$. STATA statistical analysis package was used for the dose response curve drawing in order to figure $I C_{50}$.

\section{0-Antioxidant Activity:}

The antioxidant activity was assessed at the Regional Center for Mycology and Biotechnology (RCMB), Al-Azhar University. Freshly prepared $(0.004 \% \mathrm{w} / \mathrm{v})$ methanol solution of DPPH radical was prepared and stored at $10{ }^{\circ} \mathrm{C}$ in the dark. Aliquot (40ul) of root methanolic extract dissolved in methanol was added to $3 \mathrm{ml}$ of DPPH solution. Absorbance measurements were recorded immediately with a UVvisible spectrophotometer (Milton Roy, Spectronic 1201). The decrease in absorbance at $515 \mathrm{~nm}$ was determined continuously, with data being recorded at 1 min intervals until the absorbance stabilized (16 min). The absorbance of the DPPH radical without 
antioxidant (control) and the reference compound (ascorbic acid) were also measured. All the determinations were performed in three replicates and averaged. The percentage inhibition (PI) of the DPPH radical was calculated according to the formula: $\mathrm{PI}=$ $[\{(A \mathrm{C}-A \mathrm{~T}) / A \mathrm{C}\} \times 100]$, Where $A \mathrm{C}=$ Absorbance of the control at $\mathrm{t}=0 \mathrm{~min}$. and $A \mathrm{~T}=$ absorbance of the sample + DPPH at $\mathrm{t}=16 \mathrm{~min}$. (Dawidar et al .,2015).

\section{RESULTS AND DISCUSSION}

\section{1- HPLC analysis of total phenolic and flavonoid content:}

The total concentration of phenolic and flavonoid compounds in the plant root was shown in Table 1 and 2, respectively. Results in Table 1 showed the presence of 21 phenolic compounds in which syringic acid and protocatechuic acid are of the highest concentration (1378.802 and $66.036 \mathrm{mg} / 100 \mathrm{gm}$. dried plant root powder) respectively. Table 2 revealed that hesperidin and rutin were the major flavonoids among the 10 detected compounds with concentrations of 6638.247 and $152.565 \mathrm{mg} / 100 \mathrm{gm}$. dried plant root powder, respectively.

Table1. Results of HPLC analysis of total phenolic content of Senecio glaucus subsp. coronopifolius roots:

\begin{tabular}{|l|c|}
\hline \multicolumn{1}{|c|}{ Phenolic compounds } & $\begin{array}{c}\text { Concentration (mg/100 gm. } \\
\text { dried plant root powder) }\end{array}$ \\
\hline 1- Syringic acid & 1378.802 \\
\hline 2- Gallic acid & 1.311 \\
\hline 3- Pyrogallol & 65.898 \\
\hline 4- Protocatechuic acid & 66.036 \\
\hline 5- Catechin & 11.424 \\
\hline 6- Chlorogenic acid & 13.808 \\
\hline 7- Catechol & 3.385 \\
\hline 8- Epicatechin & 1.283 \\
\hline 9- $p$ - Hydroxy benzoic acid & 3.071 \\
\hline 10- Caffeic acid & 1.283 \\
\hline 11-Vanillic acid & 4.578 \\
\hline 12- $p$ - hydroxyl cinnamic acid & 3.297 \\
\hline 13- Ferulic acid & 3.128 \\
\hline 14- Iso-Ferulic acid & 1.423 \\
\hline 15- 2 -Vanillic acid & 15.308 \\
\hline 16- Ellagic acid & 3.258 \\
\hline 17- $o$ - Coumaric acid & 0.914 \\
\hline 18- Salicylic acid & 1.814 \\
\hline 19- $3,4,5$ methoxy cinnamic acid & 11.814 \\
\hline 20- Cinnamic acid & 0.771 \\
\hline 21- Rosmarinic acid & 3.184 \\
\hline & \\
\hline
\end{tabular}


Table2. Results of HPLC analysis of total flavonoid content of Senecio glaucus subsp. coronopifolius roots:

\begin{tabular}{|l|c|}
\hline \multicolumn{1}{|c|}{ Flavonoids/aglycone } & $\begin{array}{c}\text { Concentration (mg/100 gm. dried } \\
\text { plant root powder) }\end{array}$ \\
\hline 1- Naringin & 92.497 \\
\hline 2- Rutin & 152.565 \\
\hline 3- Hesperidin & 6638.247 \\
\hline 4- Quercetrin & 98.450 \\
\hline 5- Quercetin & 9.111 \\
\hline 6- Naringenin & 6.210 \\
\hline 7- Kaempferol & 23.177 \\
\hline 8- Luteolin & 137.472 \\
\hline 9- Hesperetin & 51.596 \\
\hline 10-Apigenin & 8.870 \\
\hline
\end{tabular}

\section{2- Colorimetric estimation of total phenolic and flavonoid content:}

Total phenolic and flavonoid content of root methyl alcohol extract of Senecio glaucus subsp. coronopifolius were estimated colorimetrically. The total phenolic content value was $98.23 \pm 0.28 \mathrm{mg} / \mathrm{gm}$. dry extract and expressed as GAE (standard curve equation: $\mathrm{y}=0.0011 \mathrm{x}+0.0009, \mathrm{r}^{2}=0.9867$ ). While the content of total flavonoid was $35.9 \pm 0.17 \mathrm{mg} / \mathrm{gm}$. dry extract and expressed as QE (standard curve equation: $\mathrm{y}=$ $\left.0.005 \mathrm{x}-0.0198, \mathrm{r}^{2}=0.9774\right)$. Where $\mathrm{y}=$ the absorbance, $\mathrm{x}=$ concentratiom of total phenolic/flavonoid compounds and $r^{2}=$ the coefficient of multiple determination for multiple regression.

\section{3- Investigation of lipid content:}

\section{A- GC/MS analysis of un-saponifiable matters:}

The results of the GC/MS analysis of the un-saponifiable matter of Senecio glaucus subsp. coronopifolius leaves that are shown in Table 3 revealed the presence of 6 identified hydrocarbons. Octacosane $(11.85 \%)$ was the major identified compound followed by hexatriacontane $(4.76 \%)$ while 4 -ethyl-Tetradecane $(0.28 \%)$ was the minor identified hydrocarbon. Identification of the compounds was carried out by matching their retention times and mass spectra with those of reference compounds analyzed under the same conditions.

Table 3. Results of GC/MS analysis of un-saponifiale matters of Senecio glaucus subsp. coronopifolius leaves:

\begin{tabular}{|c|c|c|c|c|c|}
\hline Peak no. & $\mathbf{R}_{t}$ (min.) & $\mathbf{M}^{+}$ & Bp. & Name & Area \% \\
\hline 1 & 18.82 & 464 & 57 & Tritriacontane & 1.16 \\
\hline 2 & 20.48 & 254 & 57 & Octadecane & 2.04 \\
\hline 3 & 21.33 & 394 & 57 & Octacosane & 11.85 \\
\hline 4 & 22.71 & 506 & 57 & Hexatriacontane & 4.76 \\
\hline 5 & 24.65 & 364 & 43 & 3-ethyl-5- (2-ethylbutyl) - Octadecene & 1.47 \\
\hline 6 & 25.20 & 226 & 43 & 4-ethyl-Tetradecane & 0.28 \\
\hline
\end{tabular}




\section{B- GC/MS analysis of fatty acid methyl esters:}

The results of the GC/MS analysis of the saponifiable matter of Senecio glaucus subsp. coronopifolius leaves which are displayed in Table 4 indicated the presence of 12 identified fatty acid methyl esters. Linolenic acid methyl ester (31.07\%) (poly unsaturated fatty acid) was the major identified compound followed by palmitic acid methyl ester (saturated fatty acid) $(22.11 \%)$, while Tetracosanoic acid methyl ester $(0.3 \%)$ was in minor quantities. Identification of the fatty acid methyl esters was done by comparison of their retention times and pattern of fragmentation with those of reference compounds analyzed under the same conditions.

Table 4. Results of GC/MS analysis of fatty acid methyl ester of Senecio glaucus subsp. coronopifolius leaves:

\begin{tabular}{|c|c|c|c|c|c|}
\hline $\begin{array}{c}\text { Peak } \\
\text { no. }\end{array}$ & $\begin{array}{c}\mathbf{R}_{\mathrm{t}} \\
\text { (min.) }\end{array}$ & $\begin{array}{c}\mathbf{M}^{+} \text {(methyl } \\
\text { ester) }\end{array}$ & Bp. & Name & $\begin{array}{c}\text { Area } \\
\%\end{array}$ \\
\hline 1 & 18.55 & 242 & 74 & Myristic methyl ester & 5.15 \\
\hline 2 & 23.72 & 270 & 74 & Palmitic acid methyl ester & 22.11 \\
\hline 3 & 24.55 & 268 & 55 & 9-Hexadecenoic acid methyl ester & 1.69 \\
\hline 5 & 28.41 & 298 & 74 & Stearic acid methyl ester & 3.92 \\
\hline 6 & 29.21 & 296 & 55 & Oleic acid methyl ester & 0.66 \\
\hline 7 & 30.34 & 294 & 81 & 10-trans,12-cis-octadecadienoic acid methyl ester & $\mathbf{1 7 . 2 4}$ \\
\hline 8 & 31.12 & 294 & 67 & Linoleic acid methyl ester & 0.4 \\
\hline 9 & 31.97 & 292 & 79 & Linolenic acid methyl ester & 31.07 \\
\hline 10 & 32.76 & 326 & 74 & Arachidic acid methyl ester & 1.91 \\
\hline 11 & 36.81 & 354 & 74 & Behenic acid methyl ester & 1.43 \\
\hline 12 & 40.59 & 382 & 74 & Tetracosanoic acid methyl ester & 0.3 \\
\hline
\end{tabular}

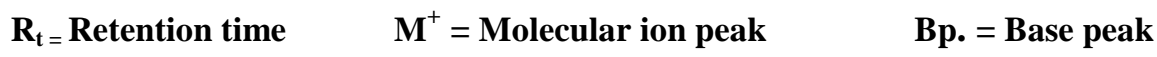

\section{4- DNA Fingerprinting using Random Amplified Polymorphic-DNA-PCR:}

The DNA fingerprint of Senecio glaucus subsp. coronopifolius was carried out as an accurate way for identification and characterization of the plant. In this study the extracted DNA of the plant was amplified using twelve decamer primers. The RAPD profile of the DNA sample showed distinguishable bands and generated 52 fragment patterns. The obtained banding profiles produced by the primers used in the RAPD analysis were represented in (Fig 1).The distribution of these bands is illustrated in Table 5.The twelve primers of arbitrary sequences produced multiple band profiles with a number of amplified DNA fragments ranging from seven when D-19 was used to the least number of fragments being one when A-15 was used. The D-19 primer was found to be the most effective in the selective discrimination of Senecio glaucus subsp. coronopifolius by the production of seven amplified DNA fragments, followed by Q-11 producing 6 DNA fragments. However, the primer H-13, M-19, P-11 and Q-05 produced 5 amplified DNA fragments and A-03, D-11, D12 and F-09 produced four amplified DNA fragments each. The primer G-20 and A-15 produced two and one amplified DNA fragments respectively, therefore, they can be considered of less contribution to the identification of Senecio glaucus subsp. coronopifolius. 
Table 5 .Molecular size in base pairs of amplified DNA fragments produced by twelve decamer primers in Senecio glaucus subsp. coronopifolius:

\begin{tabular}{|c|c|c|c|c|c|c|c|c|c|c|c|c|}
\hline $\begin{array}{l}\text { Molecular size } \\
\text { (bp) }\end{array}$ & A-03 & A-15 & D-11 & D-12 & D-19 & F-09 & G-20 & H-13 & M-19 & P-11 & Q-05 & Q-11 \\
\hline 2,505 & - & - & - & - & + & - & - & - & - & - & - & - \\
\hline 1,413 & - & - & - & - & - & - & - & - & + & & - & - \\
\hline 1,225 & - & - & - & - & - & + & - & - & - & - & - & - \\
\hline 1,182 & - & - & - & - & + & - & - & - & - & - & - & - \\
\hline 1,095 & - & - & - & + & - & - & - & - & - & - & - & - \\
\hline 862 & - & - & - & - & + & - & - & - & - & - & - & - \\
\hline 812 & - & - & - & - & - & - & - & - & + & - & - & + \\
\hline 788 & - & - & - & - & - & - & - & - & - & - & + & - \\
\hline 743 & - & - & - & - & + & - & - & - & - & - & - & - \\
\hline 700 & - & - & - & - & - & + & - & - & - & - & - & - \\
\hline 682 & - & - & - & - & - & - & - & + & - & + & - & - \\
\hline 648 & - & - & - & - & - & - & - & - & + & - & - & - \\
\hline 621 & - & - & - & + & - & - & - & - & - & - & - & - \\
\hline 584 & - & - & - & - & - & - & - & - & - & + & - & - \\
\hline 581 & - & - & + & - & - & - & - & - & - & - & - & - \\
\hline 555 & - & - & - & - & - & - & - & - & - & - & - & + \\
\hline 540 & - & - & - & - & - & + & - & - & - & - & + & - \\
\hline 500 & - & - & - & - & - & - & - & + & - & - & - & - \\
\hline 486 & - & - & - & - & + & - & - & - & - & - & - & - \\
\hline 447 & - & - & - & - & - & - & - & - & + & - & - & - \\
\hline 423 & + & + & - & - & - & - & - & - & - & + & - & - \\
\hline 411 & - & - & - & - & - & - & - & - & - & - & - & + \\
\hline 407 & - & - & - & + & - & - & - & - & - & - & - & - \\
\hline 400 & - & - & - & - & - & + & - & - & - & - & - & - \\
\hline 390 & - & - & - & - & - & - & + & - & - & - & - & - \\
\hline 370 & - & - & + & - & - & - & - & - & + & - & - & - \\
\hline 360 & - & - & - & - & - & - & - & + & - & - & - & - \\
\hline 351 & - & - & - & - & + & - & - & - & - & - & - & \\
\hline 333 & - & - & - & - & - & - & - & - & - & + & - & + \\
\hline 324 & + & - & - & - & - & - & - & - & - & - & - & - \\
\hline 318 & - & - & - & + & - & - & - & - & - & - & - & - \\
\hline 300 & - & - & - & - & - & - & - & - & - & - & + & - \\
\hline 283 & - & - & - & - & - & - & - & + & - & - & - & - \\
\hline 245 & - & - & + & - & - & - & - & - & - & - & - & - \\
\hline 231 & + & - & - & - & - & - & - & - & - & - & + & - \\
\hline 218 & - & - & - & - & + & - & - & - & - & - & - & - \\
\hline 214 & - & - & - & - & - & - & - & - & - & - & - & + \\
\hline 212 & - & - & - & - & - & - & + & - & - & - & - & - \\
\hline 182 & - & - & - & - & - & - & - & + & - & - & - & - \\
\hline 180 & + & - & - & - & - & - & - & - & - & - & - & - \\
\hline 174 & - & - & - & - & - & - & - & - & - & + & - & + \\
\hline 162 & - & - & + & - & - & - & - & - & - & - & - & - \\
\hline 128 & - & - & - & - & - & - & - & - & - & - & + & - \\
\hline Total & 4 & 1 & 4 & 4 & 7 & 4 & 2 & 5 & 5 & 5 & 5 & 6 \\
\hline
\end{tabular}

$(+)=$ Presence of bands

$(-)=$ Absence of bands

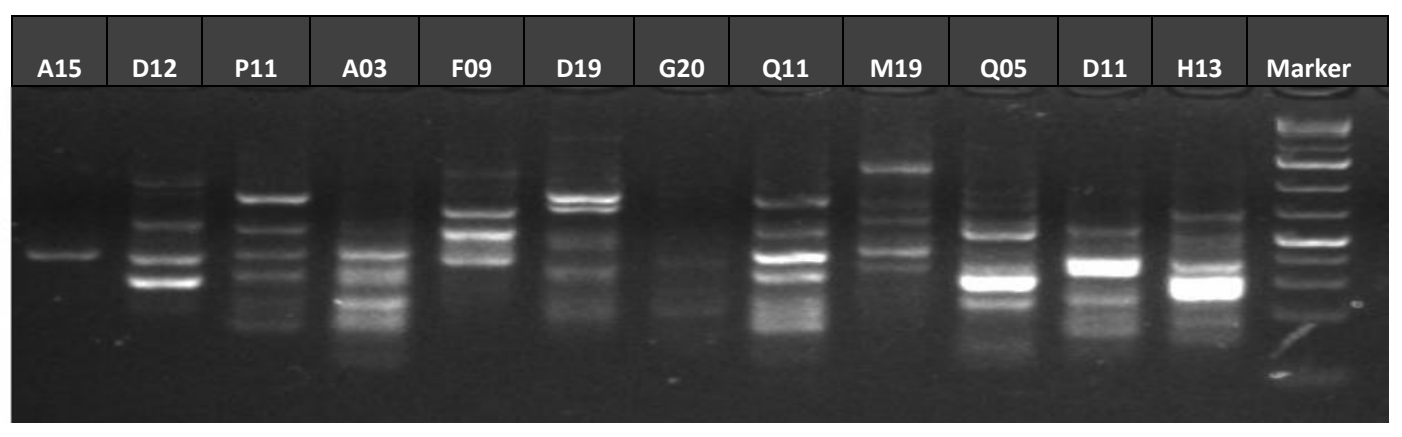

Figure 1.The RAPD-PCR products of Senecio glaucus subsp. coronopifolius using twelve decamer primers. 


\section{5- Antimicrobial activity:}

The antimicrobial activity of different root extracts was illustrated in Table 6 in which ethyl acetate extract showed promising results. MIC values of ethyl acetate extract were determined (Table 7), revealing concentrations of 3.9, 1.95, 31.25, 1.95, 1.95 and $3.9 \mu \mathrm{g} / \mathrm{ml}$ against Staphylococcus aureus, Bacillus subtilis, Klebsiella pneumoniae, Salmonella typhimurium, Aspergillus fumigates and Syncephalastrum racemosum respectively but no activity against Candida albicans. MIC results were compared against the standard antifungal agent (Amphotericin B) showing an excellent antifungal activity especially against Syncephalastrum racemosum $(3.9 \mu \mathrm{g} / \mathrm{ml})$, moderate antifungal activity against Aspergillus fumigates $(1.95 \mu \mathrm{g} / \mathrm{ml})$ and no activity against Candida albicans. Flavonoids and Phenolic compounds were reported to have antibacterial activity (Cushnie and Lamb, 2005; Aziz et al., 1998; Rauha et al., 2000). Antifungal activity was found due to the presence of flavonoid and phenolic compounds (Harborne and Williams, 2000; Zheng et al., 1996; Parvu et al., 2015). Both flavonoid and phenolic compounds were proven to be present in Senecio glaucus subsp. coronopifolius root.

Table 6. Results of antimicrobial activity of different root extracts of Senecio glaucus subsp. coronopifolius:

\begin{tabular}{|c|c|c|c|c|c|c|c|}
\hline \multirow{3}{*}{ Microorganisms } & \multirow[b]{3}{*}{ Type } & \multicolumn{6}{|c|}{ Inhibition zone diameter $(\mathrm{mm} / \mathrm{mg}$ sample) } \\
\hline & & \multicolumn{3}{|c|}{ Standard antimicrobial agents } & \multicolumn{3}{|c|}{$\begin{array}{c}\text { Roots of Senecio glaucus subsp. } \\
\text { coronopifolius }\end{array}$} \\
\hline & & $\begin{array}{c}\text { Ampicillin } \\
\text { (antibacter } \\
\text { ial } \mathbf{G}^{+} \\
\text {agent) }\end{array}$ & $\begin{array}{c}\text { Gentamycin } \\
\text { (antibacteria } \\
\text { I } \\
\text { Gagent) }\end{array}$ & $\begin{array}{c}\text { Amphoterici } \\
\text { n B } \\
\text { (antifungal } \\
\text { agent) }\end{array}$ & $\frac{\text { Alcoholic }}{\underline{\text { extract }}}$ & $\begin{array}{l}\text { Ethyl } \\
\underline{\text { acetate }} \\
\underline{\text { extract }}\end{array}$ & $\frac{\text { Acetone }}{\text { extract }}$ \\
\hline Staphylococcus aureus & $\mathbf{G}^{+}$ & $22.9 \pm 0.14$ & ------- & ------- & $17.6 \pm 0.72$ & $19.2 \pm 0.58$ & \\
\hline Bacillus subtilis & $\mathbf{G}^{+}$ & $28.3 \pm 0.37$ & -----.- & ------- & $19.1 \pm 0.25$ & $21.4 \pm 0.63$ & \\
\hline Klebsiella pneumoniae & $\mathbf{G}^{-}$ & ------ & $26.25 \pm 0.25$ & ------- & $12.7 \pm 0.58$ & $15.6 \pm 0.58$ & \\
\hline Salmonella typhimurium & $\mathbf{G}^{-}$ & ------ & $25.32 \pm 0.63$ & ------ & $15.7 \pm 0.63$ & $20.4 \pm 0.72$ & $\underset{Z}{Z}$ \\
\hline Aspergillus fumigatus & Fungus & ------- & ------- & $22.9 \pm 0.44$ & $13.8 \pm 0.63$ & $20.6 \pm 0.58$ & \\
\hline Syncephalastrum racemosum & Fungus & ------- & ------- & $19.5 \pm 0.55$ & $16.2 \pm 0.37$ & $19.1 \pm 0.44$ & \\
\hline Candida albicans & Yeast & ------- & ------- & $21.4 \pm 0.25$ & NA & NA & \\
\hline
\end{tabular}

$* \mathrm{G}^{+}=\mathrm{Gram}$ positive bacteria. ${ }^{*} \mathrm{G}^{-}=\mathbf{G r a m}$ negative bacteria. $* \mathbf{N A}=$ No activity. Data are expressed in the form of mean \pm standard deviation. 
Table 7.Minimum Inhibitory Concentrations (MIC) of Senecio glaucus subsp. coronopifolius (root ethyl acetate extract) against different microorganisms:

\begin{tabular}{|c|c|c|c|c|c|}
\hline \multirow[b]{3}{*}{ Microorganisms } & \multirow[b]{3}{*}{ Type } & \multicolumn{4}{|c|}{$\begin{array}{c}\text { Minimum Inhibitory Concentration (MIC) } \\
\mu \mathrm{g} / \mathrm{ml}\end{array}$} \\
\hline & & \multicolumn{3}{|c|}{ Standard antimicrobial agents } & \multirow[b]{2}{*}{$\begin{array}{c}\text { Senecio glaucus subsp. } \\
\text { coronopifolius } \\
\text { (Ethyl acetate extract) }\end{array}$} \\
\hline & & $\begin{array}{l}\text { Ampicillin } \\
\text { (antibacterial G } \\
\text { agent) }\end{array}$ & $\begin{array}{c}\text { Gentamycin } \\
\text { (antibacterial } \\
\text { G* agent) }^{-}\end{array}$ & $\begin{array}{c}\text { Amphotericin } \\
\text { B (antifungal } \\
\text { agent) }\end{array}$ & \\
\hline Staphylococcus aureus & $\mathbf{G}^{+}$ & 0.98 & ------- & ------- & 3.9 \\
\hline Bacillus subtilis & $\mathbf{G}^{+}$ & 0.24 & |----.-. & ------- & 1.95 \\
\hline Klebsiella pneumoniae & $\mathbf{G}^{-}$ & --.---- & 0.49 & ------- & 31.25 \\
\hline Salmonella typhimurium & $\mathbf{G}^{-}$ & ------- & 0.49 & ------ & 1.95 \\
\hline Aspergillus fumigatus & Fungus & -.----- & ------- & 0.98 & 1.95 \\
\hline Syncephalastrum racemosum & Fungus & -.----- & --.---. & 3.9 & 3.9 \\
\hline Candida albicans & Yeast & --.----- & ------- & 1.95 & NA \\
\hline
\end{tabular}

\section{6- Cytotoxic activity:}

The three pre-mentioned root extracts of Senecio glaucus subsp. coronopifolius showed dose dependent cytotoxic activity against colon carcinoma cell line (HCT116). The ethyl acetate extract displayed promising cytotoxic activity with $I C_{50}=7.39 \pm 1.2$ $\mu \mathrm{g} / \mathrm{ml}$. While the acetone extract has a moderate cytotoxic activity with $I C_{50}=12 \pm 2.1$ $\mu \mathrm{g} / \mathrm{ml}$. The lowest cytotoxic activity was exhibited by methyl alcohol extract which has $I C_{50}=37.5 \pm 3.4 \mu \mathrm{g} / \mathrm{ml}$, compared with doxorubicin as a standard cytotoxic agent with $I C_{50}=0.23 \pm 0.17 \mu \mathrm{g} / \mathrm{ml}$. The cytotoxic activity could be attributed to the presence of phenolic and flavonoid contents (Xie et al. 2009; Ren et al., 2003), which are the most frequent constituents in Senecio glaucus subsp. coronopifolius.

\section{7- Antioxidant activity:}

The free radical scavenging activity of root methanolic extract of Senecio glaucus subsp. coronopifolius based on the scavenging activity of stable DPPH revealed antioxidant activity with $I C_{50}=79.57 \pm 0.74 \mu \mathrm{g} / \mathrm{ml}$ against ascorbic acid as refrence standard $\left(I C_{50}=14.2 \pm 0.28\right)$. Flavonoids have been shown to be highly effective scavengers of most oxidizing molecules, including singlet oxygen and various free radicals (Bravo, 1998; Procházková et al., 2011). It is well known that there is a strong relationship between total phenol content and antioxidant activity, as phenols possess strong scavenging ability for free radicals due to their hydroxyl groups. Therefore, the phenolic content of plants also may directly contribute to the anti-oxidant action (Wojdylo et al., 2007; Bendini et al., 2006).

\section{Conclusion:}

This work was undertaken to investigate the roots of Senecio glaucus subsp. coronopifolius from some phytochemical and biological aspects. The richness of the 
plant roots under the study in the bioactive compounds (phenolic and flavonoid) was noted. The DNA of Senecio glaucus subsp. coronopifolius was amplified using twelve decamer primers to reveal RAPD fragments. The results suggest the use of primer D-19 for the selective discrimination of the plant. Root ethyl acetate extract exhibited promising antimicrobial and cytotoxic activity against colon carcinoma cell line (HCT116). The alcoholic extract showed antioxidant activity upon using DPPH assay.

\section{REFERENCES:}

Aziz, N.H., Farag, S.E., Mousa, L.A. and Abo-Zaid, M.A. (1998)." Comparative antibacterial and antifungal effects of some phenolic compounds." Microbios 3 (374):43-54.

Bauer, A.W., Kirby, W.M., Sherris, C. and Turck, M. (1966). "Antibiotic susceptibility testing by a standardized single disc method." American Journal of Clinical Pathology 45: 493-496.

Bendini, A., Cerretani, L., Pizzolante, L., Gallina-Toschi, T., Guzzo, F., Ceoldo, S., Marconi, A.M., Andreetta, F. and Levi, M. (2006). "Phenol content related to antioxidant and antimicrobial activity of Passiflora Spp. extracts." European Food Research and Technology 223(1):102-109.

Bohlmann, F., Zdero, C., Jakupovic, J., Grenz, M., Castro, V., King, R.M., Robinson, H. and Vincent L.P.D. (1986). "Further pyrrolizidine alkaloids and furoeremophilanes from Senecio species." Phytochemistry 25: 1151-1159.

Bohlmann, F. and Ziesche, J. (1981). "Sesquiterpenes from three Senecio species." Phytochemistry 20:469-472.

Boulos, L. (2002). "Flora of Egypt." Vol. 3, Al Hadara Publishing, Cairo, Egypt.

Bravo, L. (1998). "Polyphenols: chemistry, dietary sources, metabolism and nutritional significance." Nutrition Reviews 56:317-333.

Cheng, D., Cao, X., Cheng, J. and Roedei, E. (1993). "Diterpene glycosides from Senecio rufus." Phytochemistry 32: 151-153.

Cushnie,T.P. and Lamb, A.J. (2005). "Antimicrobial activity of flavonoids." International Journal of Antimicrobial Agents 26: 343-356.

De Pooter, H.L., De Buyck, L.F., Schamp, N.M., Aboutabl, E.A., De Bruyn, A. and Husain, S.Z. (1986). "The volatile fraction of Senecio glaucus subsp.coronopifolius." Flavour and Fragrance Journal 1(4-5):159-163.

El-Shazly, A. (2002). "Pyrrolizidine alkaloid profiles of some Senecio species." Z. Naturforsch. 57c: $429-433$.

El-Shazly, A.M. (1999). "Essential oil composition of Senecio desfontainei Druce (Compositae)." Zagazig Journal of Pharmaceutical Sciences 8:1-8. 
Fotakis, G. and Timbrell, J.A. (2006). "In vitro cytotoxicity assays: comparison of LDH, neutral red, MTT and protein assay in hepatoma cell lines following exposure to cadmium chloride." Toxicology Letters 160 (2):171-177.

Gharbo, S.A. and Habib, A.M. (1969). "Phytochemical investigation of Egyptian Senecio. Part II. Alkaloids of Senecio aegyptius, S. desfontainei, S. vulgaris, S. petasitis and S. mikanioides." Lloydia 32: 503-8.

Habib, A.M. (1981). "Alkaloids from Senecio aegyptius and S. desfontainei." Planta Med. 43: 290- 292.

Harborne, J.B. and Williams, C.A. (2000)."Advances in flavonoid research since1992." Phytochemistry 55:481-504.

Hussain, S.A., Abdul Latif, Arfan, M., Ali, M., Simpson, T.J., Cox, R.J., Shaheen, F. and Uddin, G. (2013). "A new benzoxepine derivative from Senecio desfontainei". Records of Natural Products 7(4):325-331.

Joffe, P. (2001). "Creative gardening with indigenous plants: A South African guide." Briza Publication, South Africa .P.: 16-32.

Joshi, N., Sah, G.C. and Mishra, D. (2013). "GC-MS Analysis and antimicrobial activity of essential oil of Senecio Pedunculatus." Journal of Applied Chemistry 6 (3):49-51.

Kosalec, I., Bakmaz, M., Pepeljnjak, S. and Vladimir-Knezević, S. (2004). "Quantitative analysis of the flavonoids in raw propolis from Northern Croatia." Acta Pharmacutica- zagreb 54 (1) : 65-72.

Mansour, R.M.A. and Saleh, N.A.M.(1981). "Flavonoids of three local senecio species." Phytochemistry 20:1180-1181.

Mattila, P., Astola, J. and Kumpulainen, J. (2000). "Determination of flavonoids in plant material by HPLC with diode-array and electro-array detection." Journal of Agricultural and Food Chemistry 48:5834-5841.

National Committee for Clinical Laboratory Standards (NCCLS) (1997). "Methods for dilution antimicrobial susceptibility tests for bacteria that grow aerobically". Approved standard, $4^{\text {th }}$ ed. M7-A4.

Nordenstam, B. (1977). "Senecio and liabeae-systematic review, in: The biology and chemistry of the compositae." Academic Press, London, England.P.: 799-830.

Parvu, M., Vlase, L., Parvu, A.E., Casian, O.R., Gheldiu, A.M. and Parvu, O. (2015). "Phenolic compounds and antifungal activity of Hedera helix L.(ivy) flowers and fruits." Notulae Botanicae Horti Agrobotanici 43(1):53-58.

Perez, C., Agnese, A.M. and Cabrera, J.L. (1999). "The essential oil of Senecio graveolens (Compositae): Chemical composition and antimicrobial activity tests." Journal of Ethnopharmacology 66:91-96. 
Pfaller, M. A., Burmeister, L., Bartlett, M. A. and Rinaldi, M.G. (1988). "Multicenter evaluation of four methods of yeast inoculum preparation." Journal of Clinical Microbiology 26: 1437-1441.

Procházková, D., Boušová, I. and Wilhelmová, N. (2011). "Antioxidant and pro-oxidant properties of flavonoids." Fitoterapia 82: 513-523.

Rauha, J.P., Remes, S., Heinonen, M., Hopia, A., Kähkönen, M., Kujala, T., Pihlaja, K., Vuorela, H. and Vuorela, p. (2000). "Antimicrobial effects of Finnish plant extracts containing flavonoids and other phenolic compounds." International Journal of Food Microbiology 56:3 -12.

Ren, W., Qiao, Z., Wang, H, Zhu, L. and Zhang, L. (2003). "Flavonoids: promising anticancer agents." Medicinal Research Reviews 23(4):393-534.

Rucker, G., Manns, D., Schenkel, E.P., Hartmann, R. and Heinzmann, B.M. (1999). "Triterpenes with a new 9-epi-cucurbitan skeleton from Senecio selloi." Phytochemistry 52:1587-1591.

Schishkin, B. K. and Bobrov, E.G. (1961)."Compositae - senecio in Komarov Flora URSS." Vol. 26, Doon Scientific Translation Co., India.P.: 801- 908, (English translation: 1995).

Sellappan, S., Akoh, C.C. and Krewer, G. (2002). "Phenolic compounds and antioxidant capacity of Georgia-grown blueberries and blackberries." J. Agric Food Chem. $50(8): 2432-2438$.

Vogel, A. (1989). "A textbook of practical organic chemistry". $5^{\text {th }}$ Edition, Longman Scientific and technical. Co-published with John Wiley \& Sons, Inc., New York.p.: 433, 126667.

Williams, J.G.K., Kubelik, A.R., Livak, K.J., Rafalski, J.A. and Tingey, S.V. (1990). "DNA polymorphism amplified by arbitrary primers are useful as genetic markers." Nucleic Acids Research 18 (22):6531-6535.

Wilson, A.P. (2000). "Cytotoxicity and viability assays in animal cell culture: A Practical Approach ." $3^{\text {rd }}$ ed . (edited by Masters, J.R. W.), Oxford University Press.

Wojdylo, A., Oszmiański, J. and Czemerys, R. (2007). "Antioxidant activity and phenolic compounds in 32 selected herbs." Food Chemistry 105(3): 940- 949.

Xie, Y.Y., Yuan, D., Yang, J.Y., Wang, L.H. and Wu, C.F. (2009). "Cytotoxic activity of flavonoids from the flowers of Chrysanthemum morifolium on human colon cancer Colon 205 cells." Journal of Asian Natural Products Research 11(9): 771-778.

Dawidar, A.M., Salih, L.M., Keshk, E. M. and Abdel-Mogib, M. (2015). "New flavone glycoside from Wisteria sinensis." Research Journal of Pharmaceutical, Biological and Chemical Sciences 6(5):1327-1336.

Zheng, W.F., Tan, R.X., Yang, L. and Liu, Z.L. (1996). "Two flavones from Artemisia giraldii and their antimicrobial activity." Planta Medica 62:160-162. 


\section{دراسه فيتوكيميائيه وبيولوجيه لتبات سينيسيو جلوكس تحت نوع كورونوبيفوليس الأي ينمو في مصر

يعتبر نبات سينيسيو جلوكس تحت نوع كورونوبيفوليس من العثبيات البريه الحوليه المنتشره في

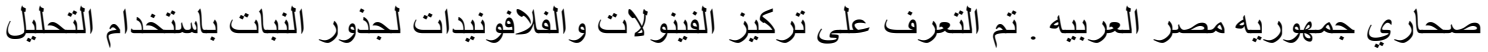

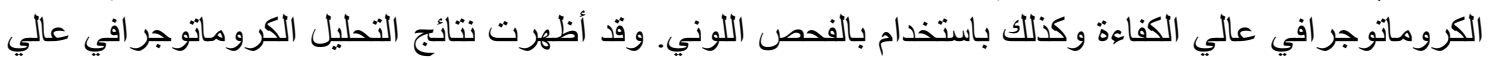

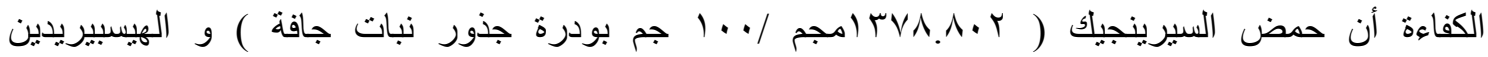

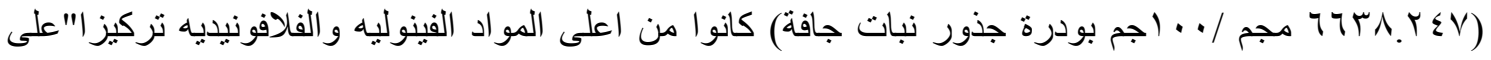

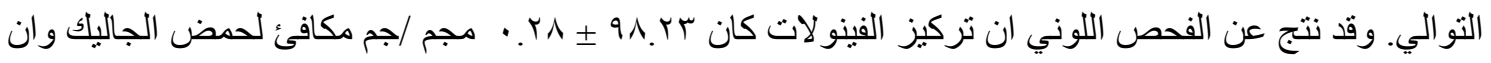

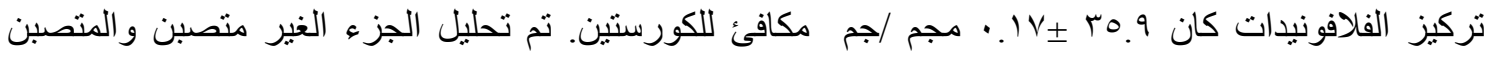

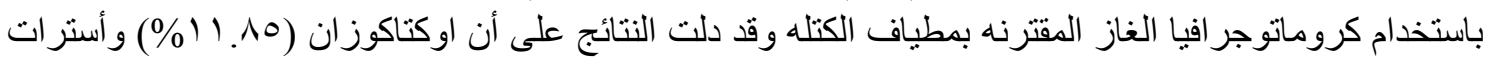

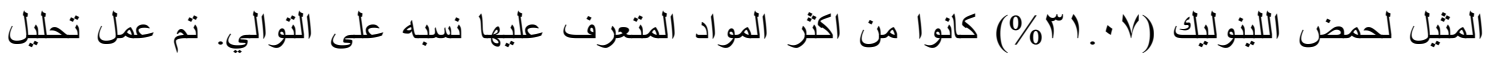

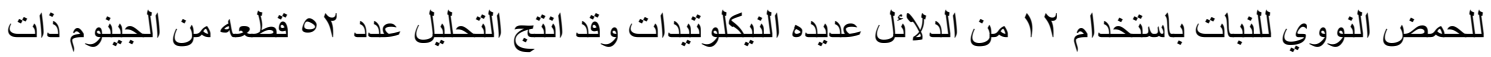

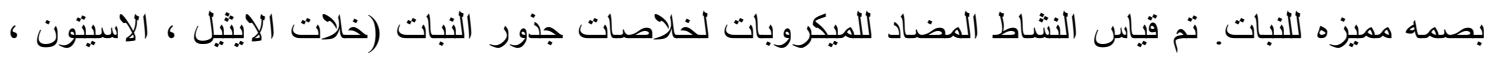







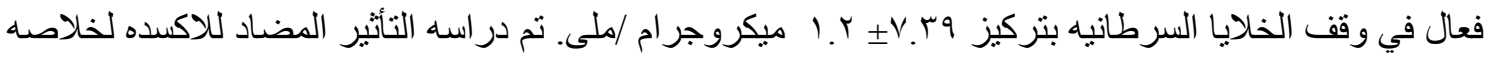

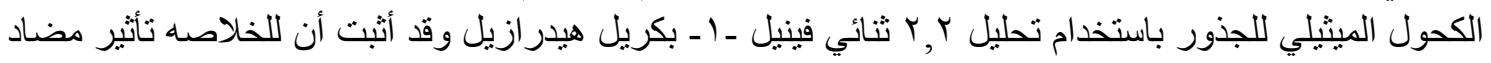

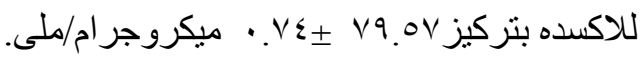

